\title{
Contamination of a boatyard for maintenance of pleasure boats
}

\author{
Britta Eklund • Lisen Johansson • Erik Ytreberg
}

Received: 10 July 2013 / Accepted: 8 December 2013 /Published online: 28 January 2014

(C) The Author(s) 2014. This article is published with open access at Springerlink.com

\begin{abstract}
Purpose The object of this study was to study a boat maintenance facility by investigating the degree of contamination and assessing how leachate water from soil affects organisms from three trophic levels.

Materials and methods Surface and subsurface (20-cm depth) soil samples were collected in a typical boatyard ( 200 boats, $12,000 \mathrm{~m}^{2}$ ) at a 70 - (station A), 90- (station B), 120-(station C) and $160-\mathrm{m}$ (station D) distance from the shoreline. Three replicate samples, $\sim 10 \mathrm{~m}$ apart, were taken at stations A, B and $\mathrm{C}$, respectively, and one replicate was taken at station $\mathrm{D}$ (i.e. altogether 20 samples with 10 at surface and subsurface, respectively). The total copper $(\mathrm{Cu})$, lead $(\mathrm{Pb})$, tin $(\mathrm{Sn})$ and zinc $(\mathrm{Zn})$ concentrations were determined for all replicates. Pooled samples from the respective stations were used for analysis of organotin compounds, irgarol and polyaromatic hydrocarbons. Leachate waters were produced from the pooled samples and used for toxicity testing with the bacterium Vibrio fischeri, the macroalga Ceramium tenuicorne and the crustacean Nitocra spinipes.

Results and discussion Very high concentrations of $\mathrm{Cu}, \mathrm{Pb}$, $\mathrm{Zn}$ were detected, with maximum values of $16,300,6,430$ and $18,600 \mathrm{mg} / \mathrm{kg} \mathrm{dw}$, respectively. Organic hazardous compounds were found in high concentrations with maximum values of 37,27 and $16 \mathrm{mg} / \mathrm{kg} \mathrm{dw}$ for tributytin (TBT), dibutyltin (DBT) and triphenyltin (TPhT), respectively. All pollutants exceeded existing guidance values for both
\end{abstract}

Responsible editor: Jianming Xu

B. Eklund $(\bowtie) \cdot$ L. Johansson

Department of Applied Environmental Science (ITM), Stockholm

University, 10691 Stockholm, Sweden

e-mail: britta.eklund@itm.su.se

E. Ytreberg

Department of Shipping and Marine Technology, Chalmers

University of Technology, 41296 Göteborg, Sweden sensitive land use and less sensitive land use by several factors, in both surface and subsurface soil. The least and worst cases of total amount of TBT $\left(12000 \mathrm{~m}^{2}\right.$ and $0.2 \mathrm{~m}$ depth) were estimated to be 10 and $122 \mathrm{~kg}$ of TBT. Leachates were shown to be toxic in all three test organisms.

Conclusions Several known hazardous pollutants were found in boatyard maintenance areas and they exceeded recommended guidance values by several factors. Leachates were shown to be toxic to test organisms of several trophic orders. This underlines that boat maintenance facilities in general should be better regulated to minimize further exposure to humans and spread of contaminants in the environment. The amounts of contaminants accumulated in these areas call for investigations of how remediation should be performed.

Keywords Antifouling paint · Boatyard · Contaminants · Tributyltin(TBT)

\section{Introduction}

Maritime transporters have battled marine biofouling, a natural process of undesirable attachment and accumulation of microorganisms, plants and animals on underwater surfaces, for the last 3,000 years (e.g. Lunn 1974; Almeida et al. 2007). The adverse effects of biofouling are well known, including higher frictional resistance, which results in increased fuel consumption and hull maintenance costs (Abarzua and Jakubowski 1995). Currently, the most common strategy for preventing biofouling is to coat the boat hull with antifouling paints containing various biocidal substances. During the 1970s and 1980s, organotin (e.g. tributyltin, TBT) formulations were the most frequently used biocide added in antifouling paints (Fent 2006). However, due to adverse effects on marine biota (Alzieu et al. 1986; Alzieu 1991; Champ 2000), in the late 1980s, several countries restricted the use of these 
formulations to leisure crafts (e.g. Alzieu 1991; EU Directive 89/677/EEC 1989). Since 2008, there has been a global ban of TBT for all sizes of ships due to the adoption of the AFS convention by the International Maritime Organization (IMO 2001). Albeit, the phasing out of TBT-based antifouling paints and of TBT and its degradation products, dibutyltin (DBT) and monobutyltin (MBT), is still observed in high concentrations in sediments at marinas, harbours and estuaries (Eklund et al. 2008). Today, copper (e.g. cuprous oxide) has replaced TBT as the main biocide on the market (Jones and Bolam 2007). For example, in Sweden, all biocide-leaching antifouling paints which are approved to be used on leisure boats contain copper as active substance (The Swedish Chemical Agency, www.kemi.se). Zinc is also a common ingredient added to paint formulations, serving as a binder/pigment (Yebra et al. 2004 and references therein; Singh and Turner 2009 and references therein). Due to the widespread use of antifouling paints, elevated concentrations of both copper and zinc have been observed worldwide in areas with high boat activity, such as marinas (Turner 2010; Kylin and Haglund 2010), harbours (Eklund et al. 2010), estuaries (Matthiessen et al. 1999) and ship lanes (Strand et al. 2003).

There is a growing body of research on release rates, fate and effects of TBT, copper and zinc leached from antifouling paints (Finnie 2006; Yebra et al. 2006; Karlsson et al. 2010; Ytreberg et al. 2010). The bio-accessibility of paint particles found in sediment and the effects on different organisms have been investigated (Turner et al. 2009a, b, c). Recently, a review was done of the marine pollution from antifouling paint particles (Turner 2010). What is studied less is how scraped off antifouling paint at boatyards ends up in the ground and how it affects biota.

The aim of this study was to do an environmental risk assessment of a Swedish boatyard. This was achieved by determining the extent of soil contamination and by producing leachate water from the soil, which was used in ecotoxicological assays.

\section{Material and methods}

\subsection{Sampling area}

The boatyard studied is located in Stockholm inner archipelago and has an area of approximately $12,000 \mathrm{~m}^{2}$. Since 1955 , the facility has been used for winter storage for approximately 200 leisure boats.

\subsection{Sampling}

The soil from the boatyard was sampled in June 2010, after the launching of boats. Four station levels were chosen for the sampling, based on their distance from the shore: stations A,
$\mathrm{B}, \mathrm{C}$ and $\mathrm{D}$, were, respectively $70,90,120$ and $160 \mathrm{~m}$ from the shore. At stations A, B and C, three replicates of soil sample, approximately $10 \mathrm{~m}$ apart from each other, were collected to determine the variation of the contamination. At station $\mathrm{D}$, only one replicate was sampled. The soil samples were collected by digging with a spade, and at each location, both surface $(0-0.5 \mathrm{~cm})$ and subsurface $(19-21 \mathrm{~cm})$ samples were collected. Thus, the total number of samples was 20. All samples were filtered through a 3-mm mesh to remove larger stones. Dry weight (dw), total organic carbon (TOC) and loss on ignition (LOI) and the concentration of copper $(\mathrm{Cu})$, lead $(\mathrm{Pb})$, tin $(\mathrm{Sn})$ and zinc $(\mathrm{Zn})$ were measured on all samples. Analyses of tin organic substances, irgarol and polyaromatic hydrocarbons (PAHs) were done on pooled samples of the respective replicates from stations $\mathrm{A}$ to $\mathrm{C}$ and from station $\mathrm{D}$. All measured substances, except PAHs, have been or are still used as active ingredient in antifouling paints.

\subsection{Leachate production}

In the leaching experiment, soil (300 g) and Milli-Q water $(500 \mathrm{~mL})$ were added to pre-cleaned glass beakers. The subsamples from sites A to $\mathrm{C}$ were pooled (i.e. 100-g soil from the three respective replicates was added to the beakers). This procedure was conducted for both surface and subsurface soil samples. After $24 \mathrm{~h}$ of incubation, with constant shaking, the soil particles were left to precipitate for an additional $72 \mathrm{~h}$. The water phase was filtered through a $0.45-\mu \mathrm{m}$ filter for dissolved metal analysis of the most commonly used metals in antifouling paints, i.e. $\mathrm{Cu}, \mathrm{Zn}$ and $\mathrm{Pb}$, and stored refrigerated $\left(4^{\circ} \mathrm{C}\right)$ before being used in ecotoxicological tests.

\subsection{Chemical analyses}

\subsubsection{Chemical analysis of soil samples}

For all soil samples, analysis of dw, TOC and LOI was performed according to standardized procedures (SS 028113-1). Metal ( $\mathrm{Cu}, \mathrm{Pb}, \mathrm{Sn}$ and $\mathrm{Zn}$ ) analyses were carried out with ICP-MS (SS-EN-ISO 17294-2) after extraction of the soil in nitric acid (SS 028150). Analyses of organic tin compounds (monobutyltin (MBT), dibutyltin (DBT), tributytin (TBT), monophenyltin (MPT), biphenyltin (DPT), triphenyltin (TPT)), polyaromatic hydrocarbons (PAH) and irgarol were performed by the laboratory ALS Scandinavia $\mathrm{AB}$, which is accredited for all analysis except irgarol. The soil was extracted with $\mathrm{MeOH} /$ hexane and, after cleaning and derivatization, the tin organic compounds were determined by GC-FPD (DIN EN ISO 17253). For measurement of PAHs, the soils were extracted with acetone-hexane-cyclohexane $(1: 2: 2)$ and the 16 most common forms of PAHs were analysed with GC-MS, based on the standard CSN EN ISO 11396. Irgarol was also determined with GC-MS. 


\subsubsection{Chemical analysis of leachate water}

All dissolved metal analyses were performed by an accredited laboratory at our department (Department of Applied Environmental Science (ITM), Stockholm University). Water samples were preserved by acidification with $\mathrm{HNO}_{3}$ (final concentration $0.2 \%$ ) and analysed for total dissolved $(<0.45 \mu \mathrm{m})$ concentrations of $\mathrm{Cu}, \mathrm{Pb}$ and $\mathrm{Zn}$ by inductively coupled plasma mass spectrometry (ICP-MS) using a Thermo $\mathrm{X}$ series II from Thermo Fisher (Bremen, Germany). The method detection limits for $\mathrm{Cu}, \mathrm{Zn}$ and $\mathrm{Pb}$ were $0.2,1.0$ and $0.05 \mu \mathrm{g} / \mathrm{L}$, respectively.

\subsection{Biological tests on leachate waters}

Since run-off from the boatyard ends up in the Baltic Sea, brackish water test organisms were used. Three organisms were used: the bacterium Vibrio fischeri, the red macroalga Ceramium tenuicorne and the harpacticoid copepod Nitocra spinipes. The latter two are common in the Baltic Sea and in marine waters.

\subsubsection{Microtox ${ }^{\circledR}$ light inhibition test}

The Microtox ${ }^{\circledR}$ toxicity tests were performed using the bioluminescent bacterium $V$. fischeri according to the Basic Test procedure described in ISO 11348-3 (ISO 2007). The Microtox $^{\circledR}$ toxicity test measures the concentration (percent leachate) that causes a $50 \%$ reduction of bioluminescence (EC50) from the bacterium. The bacterium and all solutions (i.e. reconstituent solution, diluents and osmotic adjustment solution) used in the test were obtained from Strategic Diagnostics Inc. (SDI, Newark, NJ, USA). Two replicates were used at each concentration and the test solutions were diluted in Milli-Q water and adjusted to salinity $20 \%$ using osmotic adjustment solution. For each test, nine concentrations were tested; they ranged from 0.3 to $81.9 \%$ leachate water (each treatment increasing by a factor of 2). Ten-microliter bacteria were added to each sample and the bioluminescence was measured in a photomultiplier before exposure to the leachate water and after an incubation time of $15 \mathrm{~min}$. The test medium and the bacterium were kept at $15 \pm 1^{\circ} \mathrm{C}$ during the whole procedure.

\subsubsection{Ceramium growth inhibition test}

The $C$. tenuicorne growth inhibition test was performed according to the procedure described in Eklund (2004) and ISO 2010. The stock leachate water was adjusted to 7 PSU with $\mathrm{NaCl}$ and enriched with nitrogen $(3.46 \mathrm{mg} / \mathrm{L})$, phosphorus $(0.78 \mathrm{mg} / \mathrm{L})$ and iron $(0.10 \mathrm{mg} / \mathrm{L})$. Dilution series were made of the leachate water by dilution with filtered $(30 \mathrm{~mm})$ autoclaved enriched $(\mathrm{N} 3.46 \mathrm{mg} / \mathrm{L}, \mathrm{P} 0.78 \mathrm{mg} / \mathrm{L}$ and $\mathrm{Fe} 0.10 \mathrm{mg} / \mathrm{L}$ ) natural seawater of 7 PSU. This nutrient- enriched natural seawater was also used as control. In the test, the top pieces (2-3 $\mathrm{mm}$ in length) of the alga were exposed to leachate dilutions for 1 week. The length of the algae was measured at the start and at the end of the test. The algal growth rates in the different test solutions were calculated and compared with that of a control, whereupon EC50 values were calculated. All tests were performed in sterile polystyrene Petri dishes, in four replicates for each test treatment with two pieces of algae added to each dish. During exposure, the dishes were kept at $22 \pm 2{ }^{\circ} \mathrm{C}$, a light regime of $10 \mathrm{~h}$ darkness and $14 \mathrm{~h}$ light at a light intensity of $70 \pm 7 \mu \mathrm{mol} \mathrm{m}^{-2} \mathrm{~s}^{-1}$.

\subsubsection{Nitocra larval development test (LDR)}

The LDR is a partial life cycle test based on the method described in Breitholtz and Bengtsson (2001), which measures larval development ratio (LDR) and mortality. The naupliar (larval) and copepodite (juvenile) stages are morphologically distinct in copepods and are therefore easily observed. LDR is recorded after 5 to 7 days when $\sim 50 \%$ of the control animals have reached the copepodite stage and is expressed as the percentage of copepodites among all living copepods at the end of the test. The salinity of the stock leachate water was increased to $6.5 \mathrm{PSU}$ by addition of $\mathrm{NaCl}$. Natural filtered seawater from an uncontaminated site was used as control and dilution media for the test concentrations. This water was, prior to use, filtered $(0.03-\mathrm{mm}$ paper filter) and heated to $80{ }^{\circ} \mathrm{C}$ and then $\mathrm{GF} / \mathrm{C}$-filtered $(1.2-\mu \mathrm{m}$ glass microfibre filter) to eliminate larger particles and organisms. At start of each test, ten nauplii ( $<24 \mathrm{~h}$ old) were randomly transferred to the test vials; eight replicates per treatment and control were used. The test vials were incubated in a climate chamber in darkness at $22 \pm 2{ }^{\circ} \mathrm{C}$ throughout the experiment. The crustaceans were fed with Rhodomonas salina (final density of $5 \times 10^{7}$ cells $\mathrm{mL}^{-1}$ ) at the start as well as after days 2 and 5 when $70 \%$ of the test medium was changed. Evaporation losses were compensated for by adding distilled water each time the test medium was changed. The temperature, $\mathrm{pH}$ and dissolved oxygen were measured on days 0,2 and 5 and at the end of the experiment.

\subsection{Statistical analysis}

EC50 calculations of the Microtox luminiscens inhibition test with the bacteria $V$. fischeri were performed using the software MicrotoxOmni 1.8. For calculation of EC values for the Ceramium growth inhibition test, the software RegTox ver 6.4 was used (http://eric.vindimian.9online.fr). For the crustacean assay, LDR and mortality were calculated using one-tailed Fisher's exact test and the non-parametric KruskalWallis ranking test, followed by a one-sided Mann-Whitney comparison to check for differences between the treatments and the control. Bonferroni corrections were made to correct 
for compounded alpha error for multiple comparison against the same control (i.e. differences were deemed significant at the 0.05 level if the $p$-value was $\leq 0.01$ ) equals five comparisons against the same control.

\section{Results}

3.1 Chemical concentrations in soil and soil leachates

\subsubsection{Chemical concentrations of soil samples}

The characteristics of the soil are presented in Table 1. The soil consisted of gravel, which is reflected by the low TOC and LOI at all samples from stations A, B and C. At station D, which was farthest from the shore, a higher TOC and LOI were observed, especially in the surface sample.

Table 2 presents the metal $(\mathrm{Cu}, \mathrm{Pb}, \mathrm{Zn}, \mathrm{Sn})$ composition of surface and subsurface soil samples. The values higher than the Swedish guidance values for less sensitive land use (LSL) are shown in red/dark grey and values higher than those for sensitive land use (SL) (i.e. residential areas) are shown as yellow/light grey. Guidance values exist for $\mathrm{Cu}, \mathrm{Pb}$ and $\mathrm{Zn}$ and are for SL 80, 50 and $250 \mathrm{mg} / \mathrm{kg} \mathrm{dw}$, respectively, and for LSL 200, 400 and $500 \mathrm{mg} / \mathrm{kg} \mathrm{dw}$. The Cu LSL value was exceeded in 19 of the copper samples and in the remaining sample, it was higher than the guidance value for SL. For $\mathrm{Pb} 8$, all of the ten samples from the surface and subsurface, respectively, were higher than the SL guidance value and six and seven out of ten samples from surface and subsurface, respectively, were higher than LSL. The corresponding figures for $\mathrm{Zn}$ were as follows: eight and nine of the samples from surface and subsurface, respectively, were higher than the SL guidance value and half of the surface samples and seven of the subsurface exceeded the LSL guidance value. The highest concentration of $\mathrm{Cu}(16,300 \mathrm{mg} / \mathrm{kg} \mathrm{dw})$ and $\mathrm{Zn}(18,600 \mathrm{mg} / \mathrm{kg}$ $\mathrm{dw}$ ) was found in the surface soil, which exceeded the guidance value for SL by a factor of $204(\mathrm{Cu})$ and $74(\mathrm{Zn})$. For Pb, the highest concentration was found in a subsurface sample $(6,340 \mathrm{mg} / \mathrm{kg} \mathrm{dw})$, which exceeded the guidance value for SL by a factor of 129 .

A very high variation in metal $(\mathrm{Cu}, \mathrm{Pb}, \mathrm{Sn}, \mathrm{Zn})$ concentrations was observed among the replicate soil samples at each station (Table 2). Despite the variation, the surface samples at stations A, B and C contained a significant lower concentration of $\mathrm{Cu}$ and $\mathrm{Sn}$ as opposed to the subsurface samples (Mann-Whitney nonparametric test; $\mathrm{Cu} p=0.014, \mathrm{~Pb} p=$ 0.067 , Zn $p=0.206$, Sn $p=0.017$ ). In contrast, at station $\mathrm{D}$, a notable higher metal concentration was observed in the surface sample as compared to the subsurface sample, for $\mathrm{Cu}, \mathrm{Pb}$ and $\mathrm{Zn}$ and similar concentrations for $\mathrm{Pb}$.

The concentrations of six tin organic contaminants (monobutyltin (MBT), dibutyltin (DBT), tributytin (TBT), monophenyltin (MPhT), diphenyltin (DPhT) and triphenyltin $(\mathrm{TPhT})$ ) are shown in Table 3. There are no Swedish guidance values for these substances in soil, but in Finland, the corresponding value for SL and LSL is for the sum of TBT $+\mathrm{TPhT}$ 1,000 and 2,000 $\mu \mathrm{g} / \mathrm{kg} \mathrm{dw}$, respectively (Finnish Directive 2007). In comparison to these, all subsurface samples and three of the four surface samples exceeded LSL. The highest (TBT+TPhT) concentration was measured in the surface sample from station D $(53,000 \mu \mathrm{g} / \mathrm{kg} \mathrm{dw})$ and exceeded the Finnish guidance value for SL and LSL by a factor of 53 and 26, respectively.

For all stations, the proportion of the most toxic organotin compounds (i.e. TBT, DBT and TPhT) as compared to total Sn was found to be lower in the surface soil compared to the subsurface soil (Table 3).
Table 1 Characteristics of surface $(0-0.5 \mathrm{~cm})$ and subsurface $(20 \mathrm{~cm})$ soils at a boatyard located in Stockholm archipelago. Swedish guidance values for contaminated soil exist for copper $(\mathrm{Cu})$, zinc $(\mathrm{Zn})$ and lead $(\mathrm{Pb})$ and differentiated between SL (sensitive land use) and LSL (less sensitive land use)

\begin{tabular}{|c|c|c|c|c|c|c|}
\hline \multirow[t]{2}{*}{ Location } & \multicolumn{3}{|c|}{ Surface soil $(0-0.5 \mathrm{~cm})$} & \multicolumn{3}{|c|}{ Subsurface soil $(19-21 \mathrm{~cm})$} \\
\hline & $\mathrm{dw} \%$ & LOI \% & TOC $\%$ & $\mathrm{dw} \%$ & LOI \% & TOC $\%$ \\
\hline $70 \mathrm{~m}$ from the water, $\mathrm{A} 1$ & 99.1 & 1.4 & 0.8 & 97.0 & 1.8 & 1.0 \\
\hline $70 \mathrm{~m}$ from the water, $\mathrm{A} 2$ & 99.3 & 1.5 & 0.9 & 95.3 & 2.4 & 1.4 \\
\hline $70 \mathrm{~m}$ from the water, $\mathrm{A} 3$ & 99.8 & 1.2 & 0.7 & 95.6 & 1.7 & 1.0 \\
\hline Mean \pm sd & $99.4 \pm 0.36$ & $1.4 \pm 0.15$ & $0.8 \pm 0.1$ & $96.0 \pm 0.91$ & $2.0 \pm 0.38$ & $1.1 \pm 0.23$ \\
\hline $90 \mathrm{~m}$ from the water, $\mathrm{B} 1$ & 99.3 & 1.7 & 1.0 & 97.8 & 1.7 & 1.0 \\
\hline $90 \mathrm{~m}$ from the water, B2 & 99.6 & 1.0 & 0.6 & 98.0 & 1.7 & 1.0 \\
\hline $90 \mathrm{~m}$ from the water, B3 & 99.8 & 1.2 & 0.7 & 96.5 & 1.6 & 0.9 \\
\hline Mean \pm sd & $99.6 \pm 0.25$ & $1.3 \pm 0.36$ & $0.77 \pm 0.21$ & $97.4 \pm 0.81$ & $1.7 \pm 0.06$ & $0.97 \pm 0.06$ \\
\hline $120 \mathrm{~m}$ from the water, $\mathrm{C} 1$ & 99.6 & 2.1 & 1.2 & 98.5 & 2 & 1.1 \\
\hline $120 \mathrm{~m}$ from the water, $\mathrm{C} 2$ & 99.8 & 1.3 & 0.7 & 98.8 & 1.5 & 0.9 \\
\hline $120 \mathrm{~m}$ from the water, $\mathrm{C} 3$ & 99.8 & 0.9 & 0.5 & 98.5 & 0.9 & 0.5 \\
\hline Mean \pm sd & $99.7 \pm 0.12$ & $1.4 \pm 0.61$ & $0.8 \pm 0.36$ & $98.6 \pm 0.7$ & $1.5 \pm 0.55$ & $0.83 \pm 0.31$ \\
\hline $160 \mathrm{~m}$ from the water, $\mathrm{D}$ & 97.2 & 13.9 & 7.9 & 93.2 & 7.2 & 4.1 \\
\hline
\end{tabular}


Table 2 Characteristics of surface $(0-0.5 \mathrm{~cm})$ and subsurface (19$21 \mathrm{~cm})$ soils at a boatyard located in Stockholm archipelago. Three replicates for samples A, B and C and one for sample D. Swedish guidance values for contaminated soil exist for copper $(\mathrm{Cu})$, zinc $(\mathrm{Zn})$ and lead $(\mathrm{Pb})$ and differentiated between SL (sensitive land use) and LSL (less sensitive land use). No guidance value exists for $\mathrm{Sn}$

\begin{tabular}{|c|c|c|c|c|c|c|c|c|}
\hline \multirow[b]{2}{*}{ Location } & \multicolumn{4}{|c|}{$\begin{array}{l}\text { Surface soil } \\
(0-0.5 \mathrm{~cm})\end{array}$} & \multicolumn{4}{|c|}{$\begin{array}{l}\text { Subsurface soil } \\
\qquad(19-21 \mathrm{~cm})\end{array}$} \\
\hline & $\underset{\mathrm{mg} / \mathrm{kg}}{\mathrm{Cu}}$ & $\begin{array}{l}\mathrm{Pb} \\
\mathrm{mg} / \mathrm{kg} \\
\mathrm{dw}\end{array}$ & $\begin{array}{l}\mathrm{Zn} \\
\mathrm{mg} / \mathrm{kg} \\
\mathrm{dw}\end{array}$ & $\begin{array}{l}\mathrm{Sn} \\
\mathrm{mg} / \mathrm{kg} \\
\mathrm{dw}\end{array}$ & $\underset{\mathrm{mg} / \mathrm{kg}}{\mathrm{Cu}}$ & $\begin{array}{l}\mathrm{Pb} \\
\mathrm{mg} / \mathrm{kg} \\
\mathrm{dw}\end{array}$ & $\begin{array}{c}\mathrm{Zn} \\
\mathrm{mg} / \mathrm{kg} \\
\mathrm{dw}\end{array}$ & $\begin{array}{l}\mathrm{Sn} \\
\mathrm{mg} / \mathrm{kg} \\
\mathrm{dw}\end{array}$ \\
\hline $70 \mathrm{~m}$ from the water, $\mathrm{A} 1$ & 205 & 33 & 181 & $<1$ & 479 & 336 & 288 & 20.7 \\
\hline $70 \mathrm{~m}$ from the water, $\mathrm{A} 2$ & 315 & 289 & 343 & 3.8 & 1400 & 5360 & 975 & 38.4 \\
\hline $70 \mathrm{~m}$ from the water, $\mathrm{A} 3$ & 423 & 167 & 874 & 6.9 & 214 & 170 & 232 & 8.7 \\
\hline Mean $\pm s d$ & $\begin{array}{r}314 \\
\pm 109 \\
\end{array}$ & $\begin{array}{r}163 \\
\pm 128 \\
\end{array}$ & $\begin{array}{r}466 \\
\pm 363 \\
\end{array}$ & $\begin{array}{r}5.4 \\
\pm 2.2 \\
\end{array}$ & $\begin{array}{r}698 \\
\pm 623 \\
\end{array}$ & $\begin{array}{r}1955 \\
\pm 2950 \\
\end{array}$ & $\begin{array}{r}498 \\
\pm 414\end{array}$ & $\begin{array}{r}22.6 \\
\pm 15 \\
\end{array}$ \\
\hline $90 \mathrm{~m}$ from the water, $\mathrm{B} 1$ & 461 & 2230 & 427 & 18.8 & 1840 & 6430 & 1290 & 51.4 \\
\hline $90 \mathrm{~m}$ from the water, $\mathrm{B} 2$ & 140 & 45 & 155 & $<1$ & 1430 & 1490 & 1570 & 27.8 \\
\hline $90 \mathrm{~m}$ from the water, $\mathrm{B} 3$ & 368 & 441 & 1350 & 11.1 & 1010 & 1110 & 1190 & 21.4 \\
\hline Mean \pm sd & $\begin{array}{r}323 \\
\pm 165 \\
\end{array}$ & $\begin{array}{r}905 \\
\pm 1164 \\
\end{array}$ & $\begin{array}{r}644 \\
\pm 626 \\
\end{array}$ & $\begin{array}{r}15 \\
\pm 5.4 \\
\end{array}$ & $\begin{array}{r}1427 \\
\pm 415 \\
\end{array}$ & $\begin{array}{r}3010 \\
\pm 2968 \\
\end{array}$ & $\begin{array}{r}1350 \\
\pm 197 \\
\end{array}$ & $\begin{array}{r}33.5 \\
\pm 15.8 \\
\end{array}$ \\
\hline $120 \mathrm{~m}$ from the water, $\mathrm{C} 1$ & 1600 & 1600 & 1900 & 49.3 & 1900 & 2280 & 2040 & 61.7 \\
\hline $120 \mathrm{~m}$ from the water, $\mathrm{C} 2$ & 754 & 890 & 668 & 25.2 & 1190 & 976 & 887 & 25.7 \\
\hline $120 \mathrm{~m}$ from the water, C3 & 349 & 476 & 450 & 12.2 & 388 & 276 & 389 & 5.4 \\
\hline Mean $\pm \mathbf{s d}$ & $\begin{array}{r}901 \\
+638 \\
\end{array}$ & $\begin{array}{r}989 \\
\pm 569 \\
\end{array}$ & $\begin{array}{l}1006 \\
\pm 782\end{array}$ & $\begin{array}{r}28.9 \\
+18.8 \\
\end{array}$ & $\begin{array}{r}1159 \\
\pm 757 \\
\end{array}$ & $\begin{array}{r}1177 \\
+1017\end{array}$ & $\begin{array}{l}1105 \\
\pm 847\end{array}$ & $\begin{array}{r}30.9 \\
+28.5\end{array}$ \\
\hline $160 \mathrm{~m}$ from the water, $\mathrm{D}$ & 16300 & 1640 & 18600 & 554 & 3970 & 1630 & 1410 & 259 \\
\hline
\end{tabular}

Values higher than SL are marked yellow/light grey and higher than LSL are marked red/dark grey

For the remaining analysed organotin compounds, monooctyltin, dioctyltin and tricyclohexyltin were all below the detection limit $50 \mu \mathrm{g} / \mathrm{kg} \mathrm{dw}$. Tetrabutyltin was found only at station $\mathrm{D}$ in the surface and subsurface at 71 and $58 \mu \mathrm{g} / \mathrm{kg} \mathrm{dw}$.

Table 3 Concentrations of tin organic contaminants in comparison to inorganic tin $(\mathrm{Sn})$ in a boatyard in the Stockholm archipelago. The analyses are performed on pooled samples from three replicates for $\mathrm{A}, \mathrm{B}$ and $\mathrm{C}$ and for $\mathrm{D}$ on one sample $(\mathrm{MBT}=$ monobutyltin, $\mathrm{DBT}=$ dibutyltin, $\mathrm{TBT}=$ tributyltin,
The concentrations of irgarol and PAHs and carcinogenic PAHs are presented in Table 4. There are no Swedish guidance values to compare the irgarol value with. The concentrations of both the carcinogenic and the total $\left(\sum 16 \mathrm{PAH}\right)$ were below the Swedish guidance values for soil for all analysed samples.

$\mathrm{MPhT}=$ monophenyltin, $\mathrm{DPhT}=$ diphenyltin, $\mathrm{TPhT}=$ triphenyltin). The ratio of organic Sn in percent of inorganic Sn is based on the Sn content of the three most toxic compounds: DBT, TBT and TPT

\begin{tabular}{|c|c|c|c|c|c|c|c|}
\hline & $\begin{array}{l}\text { MBT } \\
(\mathrm{mg} / \mathrm{kg} \mathrm{dw})\end{array}$ & $\begin{array}{l}\text { DBT } \\
(\mathrm{mg} / \mathrm{kg} \mathrm{dw})\end{array}$ & $\begin{array}{l}\text { TBT } \\
(\mathrm{mg} / \mathrm{kg} \mathrm{dw})\end{array}$ & $\begin{array}{l}\text { MPhT } \\
(\mathrm{mg} / \mathrm{kg} \mathrm{dw})\end{array}$ & $\begin{array}{l}\mathrm{DPhT} \\
(\mathrm{mg} / \mathrm{kg} \mathrm{dw})\end{array}$ & $\begin{array}{l}\text { TPhT } \\
(\mathrm{mg} / \mathrm{kg} \mathrm{dw})\end{array}$ & $\begin{array}{l}\text { Organic Sn in \% } \\
\text { of inorganic Sn }\end{array}$ \\
\hline \multicolumn{8}{|c|}{ Concentrations in surface soil $(0-0.5 \mathrm{~cm})$} \\
\hline $70 \mathrm{~m}$ from the water, $\mathrm{A}$ & 1.1 & 0.79 & 0.85 & 0.63 & $<0.050$ & 0.48 & 17 \\
\hline $90 \mathrm{~m}$ from the water, $\mathrm{B}$ & 1.4 & 1.2 & 2 & 0.91 & $<0.050$ & 0.26 & 10 \\
\hline $120 \mathrm{~m}$ from the water, $\mathrm{C}$ & 4.5 & 4.7 & 8 & 0.73 & $<0.050$ & 0.43 & 20 \\
\hline $160 \mathrm{~m}$ from the water, $\mathrm{D}$ & 6.5 & 27 & 37 & 1.9 & 0.190 & 16 & 6 \\
\hline \multicolumn{8}{|c|}{ Concentrations in subsurface soil $(19-21 \mathrm{~cm})$} \\
\hline $70 \mathrm{~m}$ from the water, $\mathrm{A}$ & 4.4 & 5 & 6.2 & 1 & $<0.050$ & 0.063 & 23 \\
\hline $90 \mathrm{~m}$ from the water, $\mathrm{B}$ & 5.4 & 4.1 & 5.9 & 0.61 & $<0.050$ & 0.190 & 29 \\
\hline $120 \mathrm{~m}$ from the water, $\mathrm{C}$ & 5.7 & 4.7 & 6.1 & 0.89 & $<0.050$ & 0.320 & 18 \\
\hline $160 \mathrm{~m}$ from the water, $\mathrm{D}$ & 1 & 27 & 31 & 0.73 & $<0.050$ & 1.3 & 10 \\
\hline
\end{tabular}


Table 4 Concentrations of organic contaminants in a boatyard in the Stockholm archipelago

The analyses are performed on pooled samples from three replicates for $\mathrm{A}, \mathrm{B}$ and $\mathrm{C}$ and for $\mathrm{D}$ on one sample $(\Sigma 16 \mathrm{PAH}=$ total concentration of 16 compounds analysed according to EPA. PAH carc. shows the concentration of the carcinogenic PAHs). na=not analysed

\begin{tabular}{llll}
\hline Location & $\begin{array}{l}\text { Irgarol } \\
(\mathrm{mg} / \mathrm{kg} \mathrm{dw})\end{array}$ & $\begin{array}{l}\text { PAH } 516 \mathrm{EPA} \\
(\mathrm{mg} / \mathrm{kg} \mathrm{dw})\end{array}$ & $\begin{array}{l}\text { PAH carc. } \\
(\mathrm{mg} / \mathrm{kg} \mathrm{dw})\end{array}$ \\
\hline $\begin{array}{l}\text { Concentrations in surface soil }(0-0.5 \mathrm{~cm}) \\
70 \mathrm{~m} \text { from the water, A }\end{array}$ & 0.063 & & 0.41 \\
$90 \mathrm{~m}$ from the water, B & na & 1.3 & 0.22 \\
$120 \mathrm{~m}$ from the water, C & na & 5.3 & 3.1 \\
$160 \mathrm{~m}$ from the water, D & 54 & 9.4 & 5.4 \\
Concentrations in subsurface soil $(19-21 \mathrm{~cm})$ & & 2.0 \\
$70 \mathrm{~m}$ from the water, A & 1.8 & 3.6 & 1.1 \\
$90 \mathrm{~m}$ from the water, B & na & 1.8 & 3.9 \\
$120 \mathrm{~m}$ from the water, C & na & 7.0 & 1.8 \\
$160 \mathrm{~m}$ from the water, D & 0.87 & 2.6 & \\
\hline
\end{tabular}

\subsubsection{Total amount of contaminants in the soil}

The least bad and the worst cases of the total amount of contaminants in the boatyard are shown in Table 5. The area is estimated to be $12,000 \mathrm{~m}^{2}$ and the depth of contamination is assumed to $0.2 \mathrm{~m}$. This equals $2,400 \mathrm{~m}^{3}$ of contaminated soil. With the assumption that $1 \mathrm{~L}$ soil corresponds to $1.5 \mathrm{~kg}$ soil, we have calculated least bad and worst case scenarios of the amounts of contaminants at this boatyard. The measured concentrations in the surface and the subsurface values were used to calculate a mean value. The lowest and the highest values of all the mean values have been used to illustrate the least bad and worst case scenarios.

Calculation of least and worst cases was performed as follows:

Mean of all analysed element/compound at each of the A, $\mathrm{B}, \mathrm{C}$ and $\mathrm{D}$ location $(\mathrm{Cu}, \mathrm{Pb}, \mathrm{Zn}, \mathrm{Sn}=$ six samples per location $\mathrm{A}, \mathrm{B}$ and $\mathrm{C}$ and two from $\mathrm{D}$, organotin and polyaromatic carbons $=$ two samples/location, irgarol two samples at in all two locations) was calculated. Calculation of median contamination was based on the median values of all analysed samples (See Tables 2, 3 and 4) which were multiplied with the area $\left(12,000 \mathrm{~m}^{2}\right.$ and depth $(0.2 \mathrm{~m})$.

The least bad and the worst case means for $\mathrm{Cu}$ are 1.8 and 36.5, $\mathrm{Pb} 3.8$ and 6.9, $\mathrm{Zn} 1.7$ and $36 \mathrm{t}$, respectively. For the most toxic organotin compounds, the total amount for TBT is 10 and 18 and for TPhT 3 and $5 \mathrm{~kg}$.

\subsubsection{Chemical concentrations-leachate waters}

The leachate water was analysed with respect to metal $(\mathrm{Cu}, \mathrm{Pb}$ and $\mathrm{Zn}$ ) concentrations and is presented in Table 6. Hence, no leachate data are available for tin organic compounds, PAHs and irgarol concentrations. As opposed to the metal concentrations in soil samples, the concentrations of metals were generally higher in the surface leachates as compared to the subsurface leachates.

\subsection{Toxicity of leachate water}

The effect of leachate water on $V$. fischeri, $C$. tenuicorne and $N$. spinipes in presented in Tables 7, 8 and 9. The macroalga C. tenuicorne was the most sensitive species tested, followed by the crustacean $N$. spinipes; the bacteria $V$. fischeri were the least sensitive species. $\mathrm{Cu}$ and $\mathrm{Zn}$ have been found to cause a $50 \%$ reduction in bioluminescence for the bacterium V. fischeri, at $800 \mu \mathrm{g} \mathrm{Cu} / \mathrm{L}$ and 2,000 $\mu \mathrm{g} \mathrm{Zn} / \mathrm{L}$ (Ytreberg et al. 2010). For the macroalga $C$. tenuicorne, EC50 values of 4.9-8.0 $\mu \mathrm{g} \mathrm{Cu} / \mathrm{L}$ and 21-30 $\mu \mathrm{g} \mathrm{Zn} / \mathrm{L}$ have been reported (Eklund 2005, Ytreberg et al. 2010). For the crustacean

Table 5 The total amount of elements/compounds at the investigated boatyard

\begin{tabular}{llll}
\hline Element/compound & $\begin{array}{l}\text { Median } \\
(\mathrm{kg})\end{array}$ & $\begin{array}{l}\text { Least } \\
(\mathrm{kg})\end{array}$ & $\begin{array}{l}\text { Worst } \\
(\mathrm{kg})\end{array}$ \\
\hline $\mathrm{Cu}$ & 2,200 & 1,800 & 36,500 \\
$\mathrm{~Pb}$ & 3,400 & 3,800 & 6,900 \\
$\mathrm{Zn}$ & 3,200 & 1,700 & 36,000 \\
$\mathrm{Sn}$ & 76 & 48 & 1,500 \\
$\mathrm{MBT}$ & 22 & 13 & 120 \\
$\mathrm{DBT}$ & 17 & 10 & 97 \\
TBT & 16 & 10 & 122 \\
MPhT & 2 & 1 & 31 \\
TPhT & 3 & 3 & 5 \\
Irgarol & 5 & 3 & 99 \\
PAH $\Sigma 16$ EPA & 11 & 6 & 23 \\
PAH carc. & 7 & 2 & 13 \\
\hline
\end{tabular}

The area is $12,000 \mathrm{~m}^{2}$ and the depth of contamination is assumed to be $0.2 \mathrm{~m}$. The mean of surface and subsurface values has been calculated and the lowest and highest values have been used to show the least and worst scenarios. The median value is based on all analyses of each element/ compound. The assumption is that $1 \mathrm{~L}$ soil $=1.5 \mathrm{~kg}$ soil. No values are given for DPhT because of concentrations below detection level 
Table 6 Concentrations of copper $(\mathrm{Cu})$, lead $(\mathrm{Pb})$ and zinc $(\mathrm{Zn})$ in surface and subsurface leachate waters

\begin{tabular}{|c|c|c|c|}
\hline Location & $\mathrm{Cu}(\mu \mathrm{g} / \mathrm{L})$ & $\mathrm{Pb}(\mu \mathrm{g} / \mathrm{L})$ & $\mathrm{Zn}(\mu \mathrm{g} / \mathrm{L})$ \\
\hline \multicolumn{4}{|l|}{ Surface leachate $(0-0.5 \mathrm{~cm})$} \\
\hline $70 \mathrm{~m}$ from the water, $\mathrm{A}$ & 61 & 2 & 2,117 \\
\hline $90 \mathrm{~m}$ from the water, $\mathrm{B}$ & 40 & 3 & 1,208 \\
\hline $120 \mathrm{~m}$ from the water, $\mathrm{C}$ & 117 & 14 & 583 \\
\hline $160 \mathrm{~m}$ from the water, $\mathrm{D}$ & 809 & 17 & 13,910 \\
\hline \multicolumn{4}{|c|}{ Subsurface leachate $(19-21 \mathrm{~cm})$} \\
\hline $70 \mathrm{~m}$ from the water, $\mathrm{A}$ & 31 & 2 & 94 \\
\hline $90 \mathrm{~m}$ from the water, $\mathrm{B}$ & 33 & 21 & 32 \\
\hline $120 \mathrm{~m}$ from the water, $\mathrm{C}$ & 43 & 10 & 172 \\
\hline $160 \mathrm{~m}$ from the water, $\mathrm{D}$ & 458 & 28 & 5,076 \\
\hline
\end{tabular}

The analyses are performed on pooled samples from three replicates for $\mathrm{A}, \mathrm{B}$ and $\mathrm{C}$ and for $\mathrm{D}$ on one sample

$N$. spinipes, both $\mathrm{Cu}$ and $\mathrm{Zn}$ have been reported to have significant effects on LDR at $110 \mu \mathrm{g} \mathrm{Cu} / \mathrm{L}(\mathrm{NOEC}=$ $49 \mu \mathrm{g} / \mathrm{L})$ and $400 \mu \mathrm{g} \mathrm{Zn} / \mathrm{L}(\mathrm{NOEC}=190 \mu \mathrm{g} / \mathrm{L})($ Ytreberg et al. 2010). These reported LOEC/EC50 values were subsequently used to determine if $\mathrm{Cu}$ and/or $\mathrm{Zn}$ in the leachate dilutions could be responsible for the observed toxic response or if other non-analysed contaminants may have contributed as well.

Table 7 Luminescence inhibition test with Vibrio fischeri exposed to leachate water from soil samples from a boatyard

\begin{tabular}{llll}
\hline Sample & \multicolumn{2}{l}{ Estimated conc. } \\
\cline { 2 - 4 } & $\begin{array}{l}\text { Leachate } \\
(\%)\end{array}$ & $\begin{array}{l}\mathrm{Cu} \\
(\mu \mathrm{g} / \mathrm{L})\end{array}$ & $\begin{array}{l}\mathrm{Zn} \\
(\mu \mathrm{g} / \mathrm{L})\end{array}$ \\
\hline $\begin{array}{l}\text { Surface leachate }(0-0.5 \mathrm{~cm}) \\
70 \mathrm{~m} \text { from the water, A }\end{array}$ & 165 & 101 & $\mathbf{3 , 4 9 3}$ \\
$90 \mathrm{~m}$ from the water, B & na & & \\
$120 \mathrm{~m}$ from the water, C & 180 & 211 & 1,049 \\
$160 \mathrm{~m}$ from the water, D & 16 & 129 & $\mathbf{2 , 2 2 5}$ \\
Subsurface leachate (19-21 cm) & & & \\
$70 \mathrm{~m}$ from the water, A & na & & \\
$90 \mathrm{~m}$ from the water, B & na & & \\
$120 \mathrm{~m}$ from the water, C & na & & $\mathbf{2 , 0 8 1}$ \\
$160 \mathrm{~m}$ from the water, D & 41 & 187 & \\
\hline
\end{tabular}

The tests were performed on pooled samples from three replicates for A, $\mathrm{B}$ and $\mathrm{C}$ and for $\mathrm{D}$ on one sample. Corresponding $\mathrm{Cu}$ and $\mathrm{Zn}$ concentrations are calculated from analysed leachate and bold figures denote substances most likely to be responsible for the observed toxicity based on responses to single substances. Observe extrapolation of two points. EC50 for Vibrio fischeri and $\mathrm{Cu}$ and $\mathrm{Zn}$ as single substances are 800 and $2,000 \mu \mathrm{g} / \mathrm{L}$, respectively (Ytreberg et al. 2010). na=not analysed
Table 8 Growth inhibition test with the macroalga Ceramium tenuicorne exposed to leachates in 7\%o natural seawater (NSW)

\begin{tabular}{|c|c|c|c|c|}
\hline \multirow[t]{2}{*}{ Sample } & \multirow[b]{2}{*}{$\begin{array}{l}\text { Leachate } \\
(\%)\end{array}$} & \multirow[b]{2}{*}{$\begin{array}{l}\text { Confidence } \\
\text { interval } \\
95 \%\end{array}$} & \multicolumn{2}{|c|}{ Estimated conc. } \\
\hline & & & $\begin{array}{l}\mathrm{Cu} \\
(\mu \mathrm{g} / \mathrm{L})\end{array}$ & $\begin{array}{l}\mathrm{Zn} \\
(\mu \mathrm{g} / \mathrm{L})\end{array}$ \\
\hline \multicolumn{5}{|l|}{ Surface leachate $(0-0.5 \mathrm{~cm})$} \\
\hline $70 \mathrm{~m}$ from the water, $\mathrm{A}$ & 1.35 & $(0.6-2.2)$ & 0.83 & 28.6 \\
\hline $90 \mathrm{~m}$ from the water, $\mathrm{B}$ & 1.72 & $(1.2-2.4)$ & 0.7 & 20.8 \\
\hline $120 \mathrm{~m}$ from the water, $\mathrm{C}$ & 5.52 & $(4.4-6.8)$ & 6.5 & 32.2 \\
\hline $160 \mathrm{~m}$ from the water, $\mathrm{D}$ & 0.25 & $(0-1.0)$ & 2.0 & 34.8 \\
\hline \multicolumn{5}{|c|}{ Subsurface leachate $(19-21 \mathrm{~cm})$} \\
\hline $70 \mathrm{~m}$ from the water, A & 16 & & 4.9 & 15.0 \\
\hline $90 \mathrm{~m}$ from the water, $\mathrm{B}$ & 39.7 & $(30-48)$ & 13.2 & 12.9 \\
\hline $120 \mathrm{~m}$ from the water, $\mathrm{C}$ & 5.14 & $(3.1-7.2)$ & 2.2 & 8.8 \\
\hline $160 \mathrm{~m}$ from the water, $\mathrm{D}$ & 0.31 & $(0.27-0.34)$ & 1.4 & 15.7 \\
\hline
\end{tabular}

The tests were performed on pooled samples from three replicates for A, $\mathrm{B}$ and $\mathrm{C}$ and for $\mathrm{D}$ on one sample. EC50 values (\% added leachate) are presented with $95 \%$ confidence intervals. Corresponding estimated $\mathrm{Cu}$ and $\mathrm{Zn}$ concentrations are calculated from analysed $100 \%$ leachate. Bold figures denote substance most likely to be responsible for the observed toxicity, based on responses to single substances. EC50 for Ceramium tenuicorne and $\mathrm{Cu}$ and $\mathrm{Zn}$ as single substances is 4.9-8.0 and 21$30 \mu \mathrm{g} / \mathrm{L}$, respectively (Ytreberg et al. 2010)

\subsubsection{Microtox $®$ light inhibition test to Vibrio fischeri}

Only two leachates caused a measurable toxic response on the bacterium V. fischeri (i.e. D surface (EC50 $=16 \%$ leachate) and D subsurface $(\mathrm{EC} 50=41 \%$ leachate) $)$ (Table 7). However, the bacterium was also affected by surface leachate waters from stations A and C with extrapolated EC50 of 165 and $180 \%$, respectively. Based on the toxic responses to single substances, the concentration of $\mathrm{Zn}$ in these leachate dilutions may explain the toxicity.

\subsubsection{Growth inhibition test to Ceramium tenuicorne}

All leachates were toxic to C. tenuicorne (Table 8). Of the leachates tested, those from station $\mathrm{D}$ were most toxic to the macroalga and as little as 0.25 and $0.31 \%$ leachates were enough to cause a $50 \%$ reduction in growth rate when the algae were exposed to surface and subsurface leachate, respectively. Surface leachates from stations A and B displayed high toxicity, EC50 $=1.35$ and $1.72 \%$ leachates, respectively. The $\mathrm{Zn}$ concentrations in the leakage water from the surface samples can partly explain the observed toxicity in surface samples, but it cannot for the subsurface samples. In station C, the copper concentration may also be contributing to the toxicity. 
Table 9 Larval development ratio (LDR) test with Nitocra spinipes exposed to leachates in $7 \%$ natural seawater (NSW)

\begin{tabular}{lllll}
\hline Sample & NOEC & LOEC & & Estimated conc. \\
\cline { 5 - 6 } & $\begin{array}{l}\text { Leachate } \\
(\%)\end{array}$ & $\begin{array}{l}\text { Leachate } \\
(\%)\end{array}$ & $\begin{array}{l}\mathrm{Cu} \\
(\mu \mathrm{g} / \mathrm{L})\end{array}$ & $\begin{array}{l}\mathrm{Zn} \\
(\mu \mathrm{g} / \mathrm{L})\end{array}$ \\
\hline Surface leachate $(0-0.5 \mathrm{~cm})$ & & & & \\
$70 \mathrm{~m}$ from the water, A & 3 & 9 & 5.5 & $\mathbf{1 9 1}$ \\
$90 \mathrm{~m}$ from the water, B & na & na & & \\
$120 \mathrm{~m}$ from the water, C & 45 & na & & \\
$160 \mathrm{~m}$ from the water, D & 2 & 6 & 49.0 & $\mathbf{8 3 5}$ \\
Subsurface leachate (19-21 cm) & & & \\
$70 \mathrm{~m}$ from the water, A & na & na & & \\
$90 \mathrm{~m}$ from the water, B & na & na & & \\
$120 \mathrm{~m}$ from the water, C & 18 & 18 & & \\
$160 \mathrm{~m}$ from the water, D & na & na & &
\end{tabular}

The tests were performed on pooled samples from three replicates for A, $\mathrm{B}$ and $\mathrm{C}$ and for $\mathrm{D}$ on one sample. Corresponding estimated $\mathrm{Cu}$ and $\mathrm{Zn}$ concentrations are calculated from analysed $100 \%$ leachate. Bold figures denote substance most likely to be responsible for the observed toxicity, based on responses to single substances. NOEC for Nitocra spinipes LDR and $\mathrm{Cu}$ and $\mathrm{Zn}$ as single substances is 49 and $400 \mu \mathrm{g} / \mathrm{L}$, respectively (Ytreberg et al. 2010). na $=$ not analysed

For the subsurface leachates, $\mathrm{Cu}$ could explain the toxic response at stations $\mathrm{A}$ and $\mathrm{B}$. However, at stations $\mathrm{C}$ and $\mathrm{D}$, neither $\mathrm{Cu}$ nor $\mathrm{Zn}$ could explain the toxic response.

\subsubsection{Larval development ratio (LDR) test with Nitocra spinipes}

An acute mortality test on adult crustacean was performed prior to the LDR test to identify which water had toxic capacity to influence the development of the crustacean (unpublished results). These "screening results" suggested that surface leachates $\mathrm{A}, \mathrm{C}$ and $\mathrm{D}$ and subsurface leachate $\mathrm{C}$ may have had an inherent capacity to cause an adverse effect on larval development, and consequently they were chosen for LDR testing. However, the LDR test showed that only two waters had an effect on development, i.e. surface leachates A and D (Table 9). In both cases, the concentration of $\mathrm{Zn}$ may partly be the cause of the toxicity.

\section{Discussion}

Altogether, the soil of the boatyard proved to be highly contaminated by $\mathrm{Cu}, \mathrm{Pb}, \mathrm{Zn}$, irgarol and different organotin contaminants, in both the surface and the subsurface. In most samples, the Swedish guidance values for contaminated soil for SL and LSL were exceeded by several factors. For example, the $\mathrm{SL}$ guidelines for $\mathrm{Cu}, \mathrm{Pb}$ and $\mathrm{Zn}$ were exceeded by up to 204, 60 and 74 times, respectively. The sum of TBT and TPhT was up to 53 times higher than the corresponding Finnish guidance value for SL of $1 \mathrm{mg} / \mathrm{kg} \mathrm{dw}$ (Finnish Directive 2007). In addition, in many samples, the higher guidance values of LSL were exceeded (see Tables 2 and 3). According to the European Chemical Substance Information System (2008), the hazardousness of these compounds are classified as "very high" for TBT, DBT, TPhT, PAHs and lead, "high" for copper and irgarol and "moderate" for zinc. Except for PAHs, the high concentrations of these compounds demonstrate that this site is highly contaminated.

\subsection{Occurrence and amounts of contaminants in boatyards}

Only few studies of contaminated boatyards have been found in the scientific literature. Metal concentrations were determined in three samples from surface soil of two marine leisure boatyards in UK (Turner 2013). The concentrations of $\mathrm{Cu}, \mathrm{Pb}$, $\mathrm{Zn}$ and $\mathrm{Sn}$ at both investigated sites were consistent with our findings. Similarly, very high levels of contaminants were shown in an extensive compilation of 34 investigations performed in the last 15 years of boatyards in Swedish coastal municipalities (Eklund and Eklund 2013). The concentrations were much lower in the surface compared to the subsurface at stations A and B and slightly lower at station C (Tables 2 and 3). The year before the sampling, a layer of new macadam was placed on top of the ground at the lower part of the boatyard (stations A and B). This means there had been less time for pollutants to accumulate in the surface soil there and might be the reason for the differences between the studies.

The most polluted place in the boatyard was station $\mathrm{D}$ where all measured contaminants were found in the highest concentrations in the surface soil. Station D is in the farthest end of the yard. This is also where boats in need of more extensive repairs had been placed. Often this involved removal of all paint layers, which explain the high values of all measured contaminants. Notably, TBT, which has been prohibited for use on pleasure boats since 1989 (89/677/ EEC), was also found at very high concentrations in the surface soil. The reason might be that older layers of paint that contained TBT come off in the maintenance work and accumulate in the ground. This hypothesis was also suggested by Eklund et al. $(2008,2010)$.

The reasoning used for with toxic paint layers may apply to lead paint, which was used on wooden boats. Because of its harmful properties, use of lead has been restricted since 1976 (Directive 76/769/EEC 1976; EU Directive 89/677/EEC 1989; UN 2008). Around $30 \%$ of the boats at this boat club studied are wooden, which explains the very high levels of lead both in the surface and the subsurface samples compared to the findings in Eklund and Eklund (2013). In Thailand, lead still is used extensively in repair work with wooden boats (Maharachpong et al. 2006). Maharachpong et al. studied lead 
in dust at different distances from a shipyard and found concentrations between 1 and $7,770 \mathrm{mg} \mathrm{Pb} / \mathrm{kg} \mathrm{dw}$ with the peak in the central areas, which is similar to the maximum value of $6,430 \mathrm{mg} \mathrm{Pb} / \mathrm{kg} \mathrm{dw}$ at our boatyard (Table 2).

The variation between samples was high and ranged between 30 and $150 \%$. This large variation is in accordance with the variation found in other studies (Maharachpong et al. (2006), Turner et al. (2013), Eklund and Eklund (2013)). The reason is the uneven distribution of paint flakes originating from the scraping of the boats.

The amount of hazardous metals at this boatyard is estimated to totals of several tons $\mathrm{Cu}, \mathrm{Pb}$ and $\mathrm{Zn}$ and the most toxic organotin compound TBT totals up to $122 \mathrm{~kg}$ in the worst scenario (Table 5). These calculations were made using the assumptions, i.e. that the contaminated area is $12,000 \mathrm{~m}^{2}$, the soil is contaminated $0.2 \mathrm{~m}$ down and $1 \mathrm{~L}$ of soil corresponds to $1.5 \mathrm{~kg}$.

This boatyard may be regarded as typical in size $\left(12,000 \mathrm{~m}^{2}\right)$ and in the number of boats $(200)$. The total amount based on the median value of $\mathrm{Cu}, \mathrm{Pb}, \mathrm{Zn}$ and TBT was 2.2, 3.4, 3.2 and $0.016 \mathrm{t}$, respectively (Table 5), which is a considerable amount of toxic substances. In different countries, the habit of using antifouling paints is similar, and therefore, the figures presented here may be seen as a typical example for maintenance yards for pleasure boats.

\subsection{Toxicity of contaminants found in boatyards}

The $\mathrm{Cu}, \mathrm{Pb}$, irgarol and the organotin compounds DBT, TBT and TPT are in the soil because of their use as active agents in antifouling paints (e.g. Yebra et al. 2004; Thomas and Brooks 2010). $\mathrm{Zn}$ is commonly used as a binder in the paint formulation; the high correlation between $\mathrm{Cu}$ and $\mathrm{Zn}(R=0.98)$ and $\mathrm{Sn}$ and $\mathrm{Zn}(R=0.92)$ further confirms the origin for these elements as being antifouling paints. An overview of the toxicity of substances used in antifouling paints has recently been made by Dafforn et al. (2011 and references therein).

Lead was formerly extensively used as an active substance in red lead paint, which was especially effective for preventing ship worm in wooden boats (Lunn 1974). It delays the development of children, which was the main reason for restricting its use in 1976 (Directive 76/769/EEC 1976). Still the presence of $\mathrm{Pb}$ in the surface soil was higher than LSL ( $400 \mathrm{mg} / \mathrm{kg}$ $\mathrm{dw}$ ) in six out of ten surface samples and higher than LS $(50 \mathrm{mg} / \mathrm{kg} \mathrm{dw})$ in nine out of ten samples, which implies that lead is still being spread. The high number of wooden boats, $30 \%$ of the boats, in this boat club, which differs from most boat clubs, may explain the very high concentrations of lead in the soil. Values above $400 \mathrm{mg} \mathrm{Pb} / \mathrm{kg} \mathrm{dw}$ are considered a health risk by several other authorities, including Thailand (Maharachpong et al. 2006) and the US EPA (2001). Thus, the lead values alone own suggest children should avoid this site and boat owners should take great care in doing maintenance work.

Copper has a long history of use as active ingredient in antifouling paints and today is the most widely used biocide for antifouling (Dafforn et al. 2011). This well-known toxicant affects most organisms negatively in low concentrations. Many effects of $\mathrm{Cu}$ can be found in the literature, see for example, reviews by Flemmings and Trevors (1989) and Brooks and Waldock (2009). Tests have mostly been performed on pore water or leachate water. For example, tests on three nematodes exhibited responses of EC50 around $2 \mathrm{mg} / \mathrm{L}$ on reproduction (Boyd and Williams 2003). In our study, the highest $\mathrm{Cu}$ concentrations $(0.8$ and $0.45 \mathrm{mg} / \mathrm{L})$ were found in leachates from station D, and these levels would probably affect nematodes negatively. The toxicity tests performed on leachate water on soil from this boatyard indicate that the $\mathrm{Cu}$ concentrations found (Table 6) were partly responsible for the growth inhibition of the alga C. tenuicorne (Table 8). However, it was not responsible for the toxic response to the bacteria $V$. fisheri (Table 7) and did not negatively affect the larvae development of $N$. spinipes (Table 9). Knowledge of the toxic effects of $\mathrm{Cu}$ is steadily increasing and recent work has shown that the chemosensory systems of fish and other aquatic species may be disturbed at levels as low as 5-20 $\mu \mathrm{g} / \mathrm{L}$ (McIntyre et al. 2012) and in Daphnia at $7.5 \mu \mathrm{g} / \mathrm{L}$ (Simbeya et al. 2012).

Much of the copper from the boatyard will eventually end up in adjacent waters (see Turner 2013 and references therein), and likely, the high copper levels at this boatyard will affect organisms in nearby waters and make it difficult for them to thrive. The low levels needed to disturb the chemosensory systems of organisms indicate that $\mathrm{Cu}$ leaking from boat maintenance facilities may have an even wider effect than earlier anticipated.

Zinc is commonly used as binder in paints. Zinc concentrations in soil pore water have been shown to affect, for example, soil bacteria with EC50 values of 2.5 and $9.6 \mathrm{mg} \mathrm{Zn}{ }^{2+} / \mathrm{L}$ for Escherichia coli and Pseudomonas fluorescens, respectively (Chaudri et al. 1999). The Zn concentrations found in the leachate water from the boatyard are likely responsible for part of the toxicity observed for all three test organisms used in this study (Tables 7, 8 and 9). This means that leachate water from the soil from boatyards will leak and probably affect organisms in adjacent waters.

The organotin compounds, TBT, DBT and TPhT, have all been used as active agents in antifouling paints. Due to their harmfulness, especially as endocrine disruptors, in 1989, they were prohibited for use in Europe on boats shorter than $25 \mathrm{~m}$ (Directive 89/677/EEC 1989). Still, very high concentrations were found even in the surface soil of this boatyard, with a maximum value of $53 \mathrm{mg}$ (TBT+TPT) at station D. These high levels are in accordance with what was found in many of the boatyards by Eklund and Eklund (2013). Thus, very high 
levels of organotin compounds seem to be a common feature on boat maintenance facilities. This is probably caused by the discarded paint particles that end up on the ground in connection with boat maintenance, as suggested by Eklund et al. (2008, 2010).

Degradation of TBT and TPhT has been shown to be slow; it is affected by a number of factors such as density of microbiological populations, $\mathrm{pH}$, solubility, temperature, light and oxic properties in the matrix (see, e.g. Dubey and Roy 2003; Antizar-Ladislao 2008). There are few studies on degradation of organotin compounds in soil. Paton et al. (2006) concluded that biological activity played a key role in degradation of TPhT in agricultural soil. Marcic et al. (2006) studied degradation of TBT and TPhT in sludge that was added to agricultural soil. They found that at a $\mathrm{pH}$ over 7 and a concentration over $100 \mu \mathrm{g} \mathrm{Sn} / \mathrm{kg} \mathrm{dw}$, less than $10 \%$ of TBT but about $60 \%$ of TPhT was degraded. We have no $\mathrm{pH}$ data on the soil; nevertheless, the high measured concentrations confirm that degradation especially of TBT in boatyard soil is a slow process.

In laboratory studies of marine sediments, the half-life of TBT was found to be between 360 and 775 days in an oxic environment; in an anoxic sediment, it took years to decades to degrade (Dowson et al. 1996; Dubey and Roy 2003). The sediment at this boatyard was sampled in 2007, and the values showed approximately ten times higher concentrations in the surface sediment compared to $10 \mathrm{~cm}$ deeper in the sediment (Eklund et al. 2008). This contradicts the findings that degradation is faster in the more aerobic top sediment. However, a continuous addition of TBT from the boatyard could explain these figures.

Due to slow degradation of organotin compounds, accumulation may occur in the soil. However, some degradation does take place as indicated by the relatively high concentrations of elemental Sn in all samples (Table 2) as compared to background levels in soil of approximately $3 \mathrm{mg} / \mathrm{kg} \mathrm{dw}$ (own observation). The sum of the three most toxic organotins (DBT, TBT and TPhT) in percentage of elemental Sn is in the range of 6-29\% (Table 3). Somewhat higher percentages of organotin compounds were found in the deeper samples, which might indicate a slower degradation due to a possible anoxic environment (Dubey and Roy 2003; Antizar-Ladislao 2008).

The toxicity of organotin compounds has been described in numerous reports and all the organism groups studied, from bacteria to mammals, are affected (e.g. Hoch 2001; AntizarLadislao 2008). TBT is still found in levels that give rise to imposex in molluscs as was shown in a recent study around the Korean coast (Choi et al. 2013a). Bioaccumulation of TBT is indicated by high levels in the liver (average $37 \mathrm{mg} / \mathrm{kg}$ wet weight) of the mammal finless porpoises (Neophocaena asiaeorientalis) (Choi et al. 2013b). With the high concentrations of organotin compounds at this and other boatyards, the risk of leaching into to the water is clear. Since TBT is a prioritized substance, according to the WFD, this is alarming.
Humans risk being exposed to organotin compounds in connection with maintenance work on paint on pleasure boats. Most boats today are bought on the used market and the new boat owner often does not know what type of paints that have been used on the boat. This means the boat owner may unknowingly be exposed not only to organotin compounds but also to different heavy metals and other toxic substances used in older antifouling paints (e.g. Yebra et al. 2004).

\subsection{Cocktail effect}

As shown, all the elements and compounds found in the sample are able to exhibit toxic effects in different organisms. It should be emphasized that the combined effect is probably even greater. In this study, the leachate water was only analysed for $\mathrm{Cu}, \mathrm{Pb}$ and $\mathrm{Zn}$. However, the test organisms were exposed to all the compounds in the leachates, which probably added to the observed effect. For example, TBT has been shown to be very toxic especially to growth of $C$. tenuicorne, with an EC50 of $0.49 \mu \mathrm{g} / \mathrm{L}$ (Karlsson et al. 2006). A strong correlation $\left(R^{2}\right.$ of $\left.0.88(p=0.002)\right)$ between TBT content and effect of growth inhibition of $C$. tenuicorne exposed to harbour sediments was found by Eklund et al. (2010), which further implies toxic effects from organotin substances leaking from the soil. With the high concentrations of TBT measured in the soil, it is likely that some has leaked in high enough concentrations to affect the test organisms and be partly responsible for the observed toxic effects.

Irgarol has commonly been used as a booster substance in antifouling paints and specifically affects the photosystem of plants (Yebra et al. 2004). The EC50 of growth inhibition of C. tenuicorne was shown to be $0.96 \mu \mathrm{g} / \mathrm{L}$ (Karlsson et al. 2006). Irgarol was found in particularly high concentrations at station $\mathrm{D}$, and it is likely this leachate might have reached irgarol levels sufficient to affect the alga.

With the high concentrations of many different pollutants in the soil, the toxic effect could have been expected to be even greater. However, most of the pollutants adsorb more or less firmly to organic material in the soil and do not leach out easily. This reduces the bioavailable fraction of the toxic contaminants in the leachate water. This makes it clear that biological tests should be included in future risk assessment of boatyard soil.

\subsection{Spread of contaminants from boatyards}

The paint flakes and dust generated by scraping boats will usually end up in the ground because, as a rule, the waste is not collected. Rain results in leaching from the flakes. The area of paint flakes is significantly greater than when applied to the boat hull, which accelerates the leaching of metals (Singh and Turner 2009). Experiments show that the type of water influences how much of the metals leach from the paint. 
Leaching of paint from a painted surface was shown to be notably higher in artificial seawater than in natural seawater (Ytreberg et al. 2010). Jessop and Turner (2011) proved that leaching was greater in rainwater than in tap water. We used Milli-Q water to produce leachate water because it has a $\mathrm{pH}$ of 5 and a low ion content and thus is quite similar to rainwater. Our results were comparable to that found in rainwater by Jessop and Turner (2011). The fraction of $\mathrm{Zn}$ leaching from the soil is around one magnitude higher compared to $\mathrm{Cu}$ and shows that $\mathrm{Zn}$ is more easily mobilized, which supports the data of Jessop and Turner (2011) but contradicts the findings of Singh and Turner (2009). The observations from these studies suggest that contaminants may be mobilized from paint flakes and eventually make an important contribution to the contamination of adjacent water areas.

Dust is an important means by which contaminants spread from boatyards. Spread of TBT from boat repair activities was determined in dust collected from rooftops of houses at Malta (Decelis and Vella 2007), which suggested that dust from boat maintenance areas can have impact on adjacent terrestrial grounds. This correlates well with the findings of lead content in dust in areas surrounding a boatyard in Thailand where elevated levels in household dust was found several $100 \mathrm{~m}$ from the boatyard with decreasing distance to the boatyard (Maharachpong et al. 2006). Much of the dust was transferred by windblown lead oxide from the boat repair and higher levels of lead have been detected in the blood of people living closer to the boatyard than those residing farther away (Utimanon et al. 2012). Both studies raised the apprehension that children might be affected and delayed in their development. The levels found in the soil in this study were in the same range as found in our study, which show this is a common problem in and around boat maintenance facilities.

\subsection{Health aspects on working in boat maintenance facilities}

In the above discussion, it has been clear that all the contaminants measured may pose a hazard to both the environment and to humans. Other contaminants (PCB, $\mathrm{Hg}, \mathrm{As}, \mathrm{Cd}, \mathrm{Cr}$ ), which were not analysed at this boatyard, have been found in high concentrations in many other boatyards (Eklund and Eklund 2013). Since the investigated boatyard has been functioning as a maintenance area for 60 years during which many of these substances were used for preventing organisms from fouling boats, it is possible these contaminants could be found. The bio-accessibility of metals in soils and dust contaminated by marine antifouling paint particles was investigated by Turner et al. (2009a, b, c). They used an approach that simulates the paediatric gastrointestinal tract described by Ruby et al. (1996). The authors concluded that the paint dust contained elevated concentrations of $\mathrm{Cu}, \mathrm{Cd}, \mathrm{Pb}$ and $\mathrm{Zn}$ in a form that is highly bio-accessible, and they recommended precautions for safe disposal of antifouling residues from boat maintenance. As discussed, contamination with $\mathrm{Pb}$ is considered a health risk to workers in boat repair and to inhabitants living near a boatyard (Maharachpong et al. 2006; Utimanon et al. 2012).

Our soil samples had concentrations in the same levels as found in boatyard dust by both the Turner group and the group from Thailand, which implies that the boat owners might be exposed to hazardous dust that would be taken up in their guts.

The inherently dangerous properties and the concentrations being elevated above guidance values show that the soil in the investigated boatyard, in particular, and boatyards, in general (Turner 2013; Eklund and Eklund 2013), should be considered highly polluted. They should not be used for everyday life and are highly unsuitable places for bringing small children. Many boatyards are used as camping sites during summer when the boats are in the sea. This is not recommended due to the risk of exposure to contaminated dust.

\section{Conclusions}

The soil in the investigated boatyard is highly polluted by a number of hazardous compounds such as $\mathrm{Cu}, \mathrm{Pb}, \mathrm{Zn}$ and organotin compounds (e.g. TBT, DBT and DPhT). Even if the variation is large within samples, the concentrations for these pollutants were many times higher than the recommended guidance values for residential and non-residential areas. Leachates from the soil were shown to be toxic to test organisms of several trophic orders. This and other studies emphasize that boatyards are an area that needs to be better regulated to minimize further spread of contaminants and hazardous exposure to humans. In this work, it is important that guidelines for TBT in both soil and sediment be agreed upon. The amounts of contaminants accumulated at boat maintenance facility areas call for investigations of how remediation should be performed.

Open Access This article is distributed under the terms of the Creative Commons Attribution License which permits any use, distribution, and reproduction in any medium, provided the original author(s) and the source are credited.

\section{References}

Abarzua S, Jakubowski S (1995) Biotechnological investigation for the prevention of biofouling. 1. Biological and biochemical principles for the prevention of biofouling. Mar Ecol Prog Ser 123:301-312

Almeida E, Diamantino TC, de Sousa O (2007) Marine paints: the particular case of antifouling paints. Prog Org Coat 59:2-20

Alzieu C (1991) Environmental problems caused by TBT in France: assessment, regulations, prospects. Mar Environ Res 32:7-17 
Alzieu CL, Sanjuan J, Deltreil JP, Borel M (1986) Tin contamination in Arcachon Bay: effects on oyster shell anomalies. Mar Pollut Bull 17: 494-498

Antizar-Ladislao B (2008) Environmental levels, toxicity and human exposure to tributyltin (TBT)-contaminated marine environment. A review. Environ Int 34:292-308

Boyd WA, Williams PL (2003) Comparison of the sensitivity of three neamatode species to copper and their utility in aquatic and soil tests. Environ Toxicol Chem 22:2768-2774

Breitholtz M, Bengtsson B-E (2001) Oestrogens have no hormonal effect on the development and reproduction of the harpactacoid copepod Nitocra spinipes. Mar Pollut Bull 42:879-886

Brooks S, Waldock M (2009) The use of copper as a biocide in marine antifouling paints. In: Hellio C, Yebra D (eds) Advances in Marine Antifouling Coatings and Technologies. Woodhead Publishing Limited, Cambridge, pp 492-521

Champ MA (2000) A review of organotin regulatory strategies, pending actions, related costs and benefits. Sci Total Environ 258:2171

Chaudri AM, Knight BP, Barbosa-Jefferson V, Preston S, Paton GI, Killham K, Coad N, Nicholson F, Chambers BJ, McGrath SP (1999) Determination of acute $\mathrm{Zn}$ toxicity in pore water from soils previously treated with sewage sludge using bioluminescence assays. Environ Sci Technol 33:1880-1885

Choi M, Moon H-B, Yu J, Cho H, Choi H-G (2013a) Temporal trends (2004-2009) of imposex in rock shells Thais clavigera collected along the Korean coast associated with tributyltin regulation in 2003 and 2008. Arch Environ Contam Toxicol 64:448-455

Choi M, An Y-R, Park KJ, Lee IS, Hwang D-W, Kim J, Moon H-B (2013b) Accumulation of butyltin compounds in finless porpoises (Neophocaena asiaeorientalis) from Korean coast: tracking the effectiveness of TBT regulation over time. Mar Pollut Bull 66:78-83

Dafforn KA, Lewis JA, Johnston EL (2011) Antifouling strategies: history and regulation, ecological impacts and mitigation. Mar Pollut Bull 62:453-465

Decelis R, Vella AJ (2007) Contamination of outdoor settled dust by butyltins in Malta. Appl Organomet Chem 21:239-245

Directive 76/769/EEC (July 1976) on the approximation of the laws, regulations and administrative provisions of the member states relating to restrictions on the marketing and use of certain dangerous substances and preparations

Directive 89/677/EEC (December 1989) amending for the eight time Directive 76/769/EEC on the approximation of the laws, regulations and administrative provisions of the member states to restrictions on the marketing and use of certain dangerous substances and preparations

Dowson PH, Bubb JM, Lester JN (1996) Persistence and degradation pathways of tributyltin in freshwater and estuarine sediments. Estuar Coast Shelf Sci 42:3-8

Dubey SK, Roy U (2003) Biodegradation of tributyltins (organotins) by marine bacteria. Appl Organomet Chem 17:3-8

Eklund B (2004) Growth inhibition test with the marine and brackish water macroalga Ceramium tenuicorne. ITM report no. 131. ISSN 1103-341; ISRN SU-ITM-R-123-SE

Eklund B (2005). Development of growth inhibition test with the marine and brackish water red alga Ceramium tenuicorne. Mar Pollut Bull 50:921-930

Eklund B, Eklund D (2013) Pleasure boat yard soils are highly contaminated. Environment Manage

Eklund B, Elfström M, Borg H (2008) TBT originates from pleasure boats in Sweden in spite of firm restrictions. Open Environ Sci 2:124-132

Eklund B, Elfström M, Gallego I, Bengtsson B-E, Breitholtz M (2010) Biological and chemical characterization of harbour sediments from the Stockholm area. J Soils Sediments 10:127-141

European Chemical Substance Information System (2008) http://esis.jrc. ec.europa.eu/
Fent K (2006) Worldwide occurrence of organotins from antifouling paints and effects in the aquatic environment. Handb Environ Chem 5:71-100

Finnie AA (2006) Improved estimates of environmental copper release rates from antifouling products. Biofouling: J Bioadhesion Biofilm Res 22:279-291

Finnish Directive (2007) on assessment of contaminated soil and need for sanitation. (Finska statsrådets förordning om bedömning av markens föroreningsgrad och saneringsbehov den 1 mars 2007, in Swedish)

Flemmings CA, Trevors JT (1989) Copper toxicity and chemistry in the environment: a review. Water Air Soil Pollut 44:143-158

Hoch M (2001) Organotin compounds in the environment — an overview. Appl Geochem 16:719-743

IMO (2001) International convention on the control of harmful antifouling systems on ships, IMO (the AFS Convention). London 19 October 2001

International Standardisation Organisation (ISO) (2007) Water qualitydetermination of the inhibitory effect of water samples on the light emission of Vibrio fischeri (luminiscent bacteria test) - part 3: method using freeze-dried bacteria. ISO 11348-3:2007

International Standardisation Organisation (ISO) (2010) Water qualitygrowth inhibition test with the brackish water and marine macroalga Ceramium tenuicorne. ISO 10710

Jessop A, Turner A (2011) Leaching of $\mathrm{Cu}$ and $\mathrm{Zn}$ from discarded boat paint particles into tap water and rain water. Chemosphere 83:1575-1580

Jones B, Bolam T (2007) Copper speciation survey from UK marinas, harbours and estuaries. Mar Pollut Bull 54:1127-1138

Karlsson J, Breitholtz M, Eklund B (2006) A practical ranking system to compare toxicity of anti-fouling paints. Mar Pollut Bull 52:1661-1667

Karlsson J, Ytreberg E, Eklund B (2010) Toxicity of anti-fouling paints for use on pleasure boats and vessels to non-target organisms representing three trophic levels. EnvironPollut 158:681-687

Kylin H, Haglund K (2010) Screening of antifouling biocides around a pleasure boat marina in the Baltic Sea after legal restrictions. Bull Environ Contam Toxicol 85:402-406

Lunn I (1974) Antifouling-A Brief Introduction to the Origins and Developments of the Marine Antifouling Industry. BCA Publications, Oxon, Great Britain

Maharachpong N, Geater A, Chongsuvivatwong V (2006) Environmental and childhood lead contamination in the proximity of boat-repair yards in southern Thailand - I: pattern and factors related to soil and household dust levels. Environ Res 101:294-303

Marcic C, Le Hecho I, Denaix L, Lespes G (2006) TBT and TPhT persistence in a sludged soil. Chemosphere 65:2322-2332

Matthiessen P, Reed J, Johnson M (1999) Sources and potential effects of copper and zinc concentrations in the estuarine waters of Essex and Suffolk, United Kingdom. Mar Pollut Bull 38:908-920

McIntyre JK, Baldwin DH, Beauchamp DA, Scholtz NL (2012) Lowlevel copper exposures increase visibility and vulnerability of juvenile coho salmon to cutthroat trout predators. Ecol Appl 22:1460 1471

Paton GI, Cheewasedtham W, Marr IL, Dawson JJC (2006) Degradation and toxicity of phenyltintin compounds in soil. Environ pollut 144: 746-751

Ruby MV, Davis A, Schhof R, Eberie S, Sellstone CM (1996) Estimation of lead and arsenic bioavailability using a physiologically based extraction test. Environ Sci Technol 30:422-430

Simbeya CK, Csuzdi E, Dew WA, Pyle GG (2012) Electroantennogram measurement of the olfactory response of Daphnia sp. and its impairment by waterborne copper. Ecotoxicol Environ Saf 82:80-84

Singh N, Turner A (2009) Trace metals in antifouling paint particles and their heterogeneous contamination of coastal sediments. Mar Pollut Bull 58:559-564

Strand J, Jacobsen JA, Pedersen B, Granmo Å (2003) Butyltin compounds in sediment and mollusks from the shipping strait between Denmark and Sweden. Environ Pollut 124:7-15 
Thomas KV, Brooks S (2010) The environmental fate and effects of antifouling paint biocides. Biofouling 26:73-88

Turner A (2010) Marine pollution from antifouling paint particles. Mar Pollut Bull 60:159-171

Turner A (2013) Metal contamination of soils, sediments and dust in the vicinity of marine leisure boat maintenance facilities. J Soils Sediments 13:1052-1056

Turner A, Singh N, Richards JP (2009a) Bioaccessibility of metals in soils and dusts contaminated by marine antifouling paint particles. Environ Pollut 157:1526-1532

Turner A, Pollock H, Brown MT (2009b) Accumulation of $\mathrm{Cu}$ and $\mathrm{Zn}$ from antifouling paint particles by the marine macroalga, Ulva lactuca. Environ Pollut 157:2314-2319

Turner A, Barrett M, Brown MT (2009c) Processing of antifouling paint particles by Mytilus edulis. Environ Pollut 157:215-220

UN environment program (2008) Interim review of scientific information on lead. http://www.chem.unep.ch/pb_and_cd/SR/Files/2008/ UNEP-Lead-review-Interim-APPENDIX-mar102008.pdf
US EPA (2001) Residential lead hazards standards-TSCA section 403. Available at: http://yosemite.epa.gov/opei/rulegate.nsf/byrin/2070aj82?opendocument

Utimanon O, Geater A, Chongsuvivatwong V, Saetia W, Verkasalo PK (2012) Relative contribution of potential modes of surface dust lead contamination in the homes of boatyard caulkers. J Occup Health $54: 165-175$

Vindimian É. REGTOX-EV6.xls. Regtox 6.3 software program. Xls, http://eric.vindimian.9online.fr

Yebra DM, Kiil S, Dam-Johansen K (2004) Antifouling technologypast, present and future steps towards efficient and environmentally friendly antifouling coatings. Prog Org Coat 50:75-104

Yebra DM, Kiil S, Weinell CE, Dam-Johansen K (2006) Dissolution rate measurements of sea water soluble pigments for antifouling paints: ZnO. Prog Org Coat 56:327-337

Ytreberg E, Karlsson J, Eklund B (2010) Comparison of toxicity and release rates of $\mathrm{Cu}$ and $\mathrm{Zn}$ from anti-fouling paints leached in natural and artificial brackish seawater. Sci Total Environ 408:2459-2466 